\title{
PERLINDUNGAN HUKUM TERHADAP KONSUMEN ATAS PENJUALAN OBAT YANG TIDAK SESUAI LABEL
}

\author{
Muhammad Ferdian \\ Universitas Dirgantara Marsekal Suryadarma \\ Jl. Angkasa Raya No. 1, Jakarta Pusat - DKI Jakarta \\ Email: muhammadferdian@gmail.com
}

\begin{abstract}
Abstrak
Persaingan bisnis tidak dapat dipisahkan dari penipuan dari pelaku bisnis atau pelaku bisnis yang buruk. Pelaku bisnis yang tidak memiliki kemampuan untuk bersaing dengan pelaku bisnis yang kuat sering berpikiran pendek dengan melahirkan kebijakan yang tidak benar bahkan dengan mengorbankan konsumen. Sehingga itu diperlakukan keamanan produk obat sebelum didistribusikan ke pasar. Tulisan ini menggunakan metode penelitian hukum yuridis normatif (penelitian normatif) dengan spesifikasi penelitian deskriptif analitik yang menggunakan data sekunder. Prosedur pengumpulan data adalah dalam bentuk dokumentasi catatan atau kutipan, pencarian literatur hukum, buku-buku dan lain-lain yang berkaitan dengan identifikasi masalah baik offline maupun online yang kemudian dianalisis melalui metode analisis konten (content analysis method) dengan fokus pada masalah bagaimana perlindungan hukum bagi konsumen yang membeli obat tidak sesuai dengan label, dan bagaimana konsekuensi hukum untuk produk obat yang tidak memenuhi standar pelabelan. Dari hasil penelitian diketahui bahwa perlindungan hukum terhadap konsumen yang membeli obat yang tidak sesuai dengan label adalah untuk kepentingan masyarakat, oleh karena itu merupakan harapan semua orang di setiap negara di dunia untuk dapat untuk membuatnya terjadi.
\end{abstract}

\section{Kata Kunci: Perlindungan, Hukum, Konsumen, Obat, Label}

\section{Abstract}

Business competition cannot be separated from fraud from business people or bad business people. Business actors who do not have the ability to compete with strong business actors are often short-minded by giving birth to policies that are not true even at the expense of consumers. So that it was treated security of medicinal products before being distributed to the market. This writing uses normative juridical legal research methods (normative research) with descriptive analytical research specifications that use secondary data. The procedure of data collection is in the form of documentation of notes or quotations, search of legal literature, books and others related to the identification of problems both offline and online which are then analyzed through the content analysis method (centent analysis method) with a focus on the issue of how legal protection for consumers who buy drugs not in accordance with the label, and how the legal consequences for drug products that do not meet labeling standards. From the results of the study it is known that legal protection of consumers who buy drugs that are not in accordance with the label is in the interests of the community, therefore it is the hope of all people in every country in the world to be able to make it happen.

Keywords: Protection, Law, Consumer, Medicine, Label 
DE LEGA LATA

Jurnal Ilmu Hukum

FAKULTAS HUKUM UMSU
Perlindungan Hukum Terhadap...(Muhammad Ferdian) Volume 3 Nomor 2, Juli-Desember 2018, 166-184 DOI: https://doi.org/10.30596/dll.v3i2.3158

\section{PENDAHULUAN}

Pembangunan nasional di Indonesia merupakan cerminan untuk meningkatkan kemakmuran dan kesejahteraan rakyat Indonesia secara adil, dan merata dalam segala aspek kehidupan yaitu dengan tersedianya kebutuhan pokok seperti sandang (pakaian), pangan (makanan), papan (perumahan) yang layak, sebagai wujud pembangunan dan cita-cita sebagaimana yang diamanatkan dalam pancasila dan UUD 1945 (UUD).

Obat dan makanan merupakan kebutuhan pokok bagi manusia yang harus dipenuhi sebagai energi dalam menjalankan aktifitasnya, manusia memerlukan obat dan makan yang cukup, sehat dan bergizi untuk mempertahankan hidup, maka Negara memebrikan perlindungan, mengawasi dan mengatur peredaran produk obat dan makanan di pasar karena berkaitan dengan keselamatan, kesehatan, dan keamanan terhadap warganya.

Perlindungan terhadap kesehatan sebagai hak dasar setiap warga Negara merupakan salah satu kewajiban Negara sesuai dengan yang tercantum dalam Undang-Undang Dasar Republik Indonesia yakni dalam Pembukaan Alinea Keempat yaitu:

Melindungi segenap bangga Indonesia dan seluruh tumpah darah Indonesia dan untuk memajukan kesejahteraan umum, mencerdaskan kehidupan bangsa, dan ikut melaksanakan ketertiban umum, mencerdaskan kehidupan bangsa, dan melaksanakan ketertiban dunia yang berdasarkan kemerdekaan, bagi manusia dalam rangka mewujudkan kesejahteraan dan kecerdasan bangsa dan ikut melaksanakan ketertiban dunia yang berdasarkan perdamaian abadi dan keadilan sosial". Perlindungan di atas bertujuan untuk memajukan pembangunan nasional dan sumber daya manusia yang berkualitas.

Pasal 27 ayat (2) Undang-Undang Dasar Republik Indonesia Tahun 1945 menyebutkan bahwa "tiap-tiap warga Negara berhak atas pekerjaan dan penghidupan yang layak bagi kemanusiaan". "Untuk memperoleh hidup yang layak bagi kemanusiaan dalam rangka mewujudkan kesejahteraan dan kecerdasan, perlu penyesuaian barang dan jasa dalam jumlah yang cukup, kualitas yang baik" (Janus Sidabalok, 2014, h. 1).

Bagian dari kebutuhan atas barang adalah pangan yang didalamnya termak obat dan makanan yang perlu disediakan oleh baik Negara atau swasta untuk mendapatkan keuntungan dalam bentuk usaha. Pemerintah sangat memperhatikan agar pangan/ makanan (termasuk obat) dapat tersedia dengan cukup disegala pelosok tanah air, agar semua lapisan konsumen dapat terjangkau dan mampu membeli makanan (termaksuk obat) tersebut (Calina Tri Siwi Kristiyanti, 2008, h. 169).

Para pelaku usaha atau pembisnis terutama industri obat dan makanan melihat potensi pasar atas produknya dengan jumlah konsumen yang banyak saling bersaing untuk menguasai pasar dengan tujuan mendapatkan keuntungan setinggi mungkin. Persaingan ini tidak lepas dari adanya kecurangan dari pelaku usaha atau pembisnis jahat. Pelaku usaha yang tidak memiliki kemampuan untuk bersaing dengan pelaku usaha yang kuat, kerap sekali berpikiran 
DE LEGA LATA

Jurnal Ilmu Hukum

FAKULTAS HUKUM UMSU
Perlindungan Hukum Terhadap...(Muhammad Ferdian) Volume 3 Nomor 2, Juli-Desember 2018, 166-184 DOI: https://doi.org/10.30596/dll.v3i2.3158

pendek dengan melahirkan kebijakan-kebijakan yang tidak benar walaupun dengan mengorbankan konsumen (Dedi Harianto, 2010, h. 10). Sehingga diperlakukan keamanan atas produk obat sebelum di distribusikan kepasar.

Menurut Pasal 1 Undang-Undang Nomor 8 Tahun 1999 tentang Perlindungan Konsumen menyatakan perlindungan konsumen selanjutnya disingkat dengan UndangUndang Nomor 8 Tahun 1999 tentang Perlindungan Konsumen adalah:

Segala upaya yang menjamin adanya kepastian hukum untuk memberi perlindungan kepada konsumen. Sedangkan yang dimaksud konsumen adalah setiap orang pemakai barang atau jasa yang tersedia dalam masyarakat, baik bagi kepentingan diri sendiri, keluarga, orang lain maupun mahluk hidup lain dan tidak untuk diperdagangkan.

Pasal 7 huruf a Undang-Undang Nomor 8 tahun 1999 tentang Perlindungan Konsumen, menegaskan yaitu:

Salah satu kewajiban pelaku usaha yaitu harus beriktikad baik dalam melakukan usahanya, antara lain tidak dibenarkan mencampurkan bahan kimia/bahan tidak layak edar pada produk obat serta mencantumkan kode yang mana produk obat yang diproduksi pada kenyataannya tidak memenuhi standarisasi mutu pangan.

Korban keracunan bukan berita baru yang kita dengar bahkan merenggut korban yang banyak, hal ini tidak jauh akibat mengkonsumsi obat yang beredar tidak sesuai dengan mutu pangan, selain itu banyak masyarakat yang menderita sakit tipus bahkan kanker yang tak lain akibat mengkonsumsi obat yang tidak layak untuk di konsumsi secara terus menerus. Di kota Medan peredaran obat yang tidak sesuai dengan label dapat mencapai 5-10\% per tahun.

Di dalam kajian tentang perlindungan hukum terhadap konsumen atas penjualan obat yang tidak sesuai dengan label, sehingga yang menjadi fokus permasalahn dalam penulisan ini adalah bagaimana perlindungan hukum terhadap konsumen yang membeli obat tidak sesuai dengan label, bagimana akibat hukum bagi produk obat yang tidak memenuhi standar pelabelan. Harapan tulisan ini dapat bermanfaat baik secara teori maupun praktis bagi khalayak luas dalam rangka perlindungan hukum terhadap konsumen atas penjualan obat yang tidak sesuai dengan label.

\section{METODE PENELITIAN}

Penulisan ini menggunakan metode penelitian hukum yuridis normatif (normatif research), yaitu penelitian hukum yang dilakukan dengan cara meneliti bahan pustaka atau data skunder (Seokanto dan Sri Muji, 2003, h. 15). Spesifikasi penelitian dalam penulisan ini berupa penelitian deskriptif analistis. Deskriptif adalah menunjukan komparasi atau hubungan seperangkat data dengan seperangkat data yang lain, dan maksudnya adalah untuk memberikan gambaran, menelaah, menjelaskan dan menganalisis (Soekanto, 1996, h. 63).

Sesuai jenis dan sifat penelitiannya, maka sumber data yang digunakan dalam penulisan ini adalah data skunder yang terdiri dari bahan hukum primer berupa; Undang-Undang Dasar 1945 (UUD 1945), Kitab Undang-Undang Hukum Perdata (KUHPerdata), Undang-Undang Nomor 8 tahun 1999 tentang Perlindungan Konsumen, Undang-Undang Republik Indonesia 
Jurnal Ilmu Hukum

FAKULTAS HUKUM UMSU
Perlindungan Hukum Terhadap...(Muhammad Ferdian) Volume 3 Nomor 2, Juli-Desember 2018, 166-184 DOI: https://doi.org/10.30596/dll.v3i2.3158

No. 36 Tahun 2009 Tentang Kesehatan, PP No. 51 Tahun 2009 Tentang Pekerjaan Kefarmasian, Peraturan Badan Pengawas Obat dan Makanan Nomor 12 Tahun 2018 Tentang Organisasi dan Tata Kerja Unit Pelaksana Teknis di Lingkungan Badan pengawas Obat dan Makanan. Bahan hukum sekunder terdiri dari buku-buku, jurnal ilmiah, makalah dan artikel ilmiah yang dapat memberi penjelasan tentang bahan hukum primer. Bahan hukum tersier; berupa Kamus Besar Bahasa Indonesia (KBBI) dan lain sebagainya dalam menemukan defenisi dari istilah-istilah dalam membahas tentang perlindungan hukum terhadap konsumen atas penjualan obat yang tidak sesuai dengan label.

Prosedur yang digunakan untuk mengumpulkan data dalam penilitian ini berupa dokumentasi yaitu pedoman yang digunakan berupa catatan atau kutipan, penelusuran literatur hukum, buku-buku dan lainnya yang bertalian dengan identifikasi masalah dalam penilitian ini dengan cara offline maupun online. Analisa bahan hukum dilakukan dengan menggunakan metode analisa konten (centent analysis method) yang dilakukan dengan menguraikan materi peristiwa hukum atau produk hukum secara rinci guna memudahkan interpretasi dalam pembahasan (Marzuki, 2011, h. 171).

\section{PEMBAHASAN}

\section{Perlindungan Hukum Terhadap Konsumen Yang Membeli Obat Tidak Sesuai Dengan Label}

Perlindungan konsumen merupakan bagian yang tidak dapat terpisahkan dari kegiatan bisnis yang sehat. Dalam kegiatan bisnis yang sehat terhadap keseimbangan perlindungan hukum antara konsumen dengan pelaku usaha. Tidak adanya perlindungan yang seimbang menyebabkan konsumen berada pada posisi yang lemah, apalagi jika produk yang dihasilkan merupakan jenis produk yang terbatas, sehingga pelaku usaha dapat menyalahgunakan posisinya yaitu dengan cara memonopoli produksi dan pemasaran, hal ini tentu saja akan sangat merugikan konsumen.

Perlindungan konsumen merupakan kepentingan masyarakat, oleh karena itu menjadi harapan bagi semua masyarakat di setiap Negara yang ada di dunia untuk dapat mewujudkannya. Wujud dari perlindungan konsumen adalah dari berbagai hubungan yamg satu sama lain saling terkait. Hubungan antara konsumen, pelaku usaha dan pemerintah (Aulia Muthiah, 2018 h.15). Yang dimana hubungan antara pelaku usaha dengan konsumen merupakan hubungan yang terus menerus dan berkesinambungan.

Hubungan tersebut terjadi karena keduanya memang saling mengkehendaki dan mempunyai tingkat ketergantungan yang sangat tinggi antara yang satu dengan yang lain. Dalam menguraikan konsep hubungan pelaku usaha dan konsumen mengemukakan

Kunci pokok perlindungan hukum bagi konsumen adalah bahwa konsumen dan pelaku usaha saling membutuhkan. Produksi tidak ada artinya kalau tidak ada yang mengkonsumsinya dan produk yang di konsumsi secara aman dan memuaskan, pada gilirannya akan merupakan promosi gratis bagi pelaku usaha (Abdul Halim Barkatullah, 2010, h. 14). 
DE LEGA LATA

Jurnal Ilmu Hukum

FAKULTAS HUKUM UMSU
Perlindungan Hukum Terhadap...(Muhammad Ferdian) Volume 3 Nomor 2, Juli-Desember 2018, 166-184 DOI: https://doi.org/10.30596/dll.v3i2.3158

Pelaku usaha sangat membutuhkan dan sangat bergantungan pada dukungan konsumen sebagai pelanggan. Tanpa dukungan konsumen tidak mungkin pelaku usaha dapat mempertahankan kelangsungan usahanya. Sebaliknya, kebutuhan konsumen dangat berhantung dari hasil produksi pelaku usaha. Hubungan antara pelaku usaha dan konsumen yang berkelanjutan terjadi sejak proses produksi, distribusi pada pemasaran hingga penawaran. Rangkaian kegiatan tersebut merupakan rangkaian perbuatan hukum yang mempunyai akibat hukum, baik terhadap semua pihak maupun hanya dengan pihak tertentu saja.

Hal tersebut dimanfaatkan oleh pelaku usaha dalam suatu sistem distribusi dan pemasaran produk barang guna dalam suatu sistem tingkat produktifitas dan efektifitas tertentu dalam rangka mencapai sasaran usaha. Padatahap hubungan penyaluran dan distribusi tersebut menghasilkan suatu hubungan yang sifatnya massal (Abdul Halim Barkatullah, 2010, h.15). Setiap orang, pada satu waktu, dalam posisi tunggal/sendiri maupun berkelompok bersama orang lain, dalam keadaan apa pun pasti menjadi konsumen untuk suatu produk barang dan jasa tertentu. Keadaan yang universal sehingga konsumen tidak mempunyai kedudukan yang 'aman'. Oleh karena itu, secara mendasar konsumen juga membutuhkan perlindungan hukum yang sifatnya universal. Mengingat lemahnya kedudukam konsumen pada umumnya dibandingkan dengan kedudukan produsen yang relatif lebih kuat dalambanyak hal, maka pembahasan perlindungan konsumen akan selalu terasa aktual dan selalu penting untuk dikaji ulang.

Perlindungan terhadap konsumen dipandang secara material maupun formal makin terasa sangat penting, mengingat makin lajunya ilmu pengetahuan dan teknologi yang merupakan motor penggerak bagi produktivitas dan efisiensi produsen barang atau jasa yang dihasilkannya dalam rangka mencapai sasaran usaha. Dalam rangka mengejar dan mencapai kedua hal tersebut, akhirnya baik langsung atau tidak langsung, konsumenlah yang pada umumnya akan merasakan dampaknya. Dengan demikian, upaya-upaya untuk memberikan perlindungan yang memadai terhadap kepentingan konsumen merupakan suatu hal yang penting dan mendesak untuk segera dicari solusinya, terutama di Indonesia, mengingat sedemikan kompleksnya permasalahan yang menyangkut perlindungan konsumen, lebih-lebih menyongsong era perdagangan bebas yang akan datang (Celina Tri Siwi Kristianti, 2018, h. $5)$.

Kelemahan konsumen dibandingkan dengan pelaku usaha dapat terlihat pada factor ekonomi, pengetahuan, psikologis, maupun pendidikan. Menurut hasil penelitian BPHN (Badan Pembinaan Hukum Nasional), faktor-faktor penyebab lemahnya konsumen juga dapat muncul karena hal-hal sebagai beikut: (Intan Nur Rahmawati,dkk, 2014, h. 44)

a. Masih rendahnya tingkat kesadaran konsumen akan haknya

b. Belum terkondisinya masyarakat konsumen karena masyarakat belum tahu hak-hak dank ke mana hak-haknya disalurkan jika mendapatkan kesulitan atau kekurangan dari standard barang atau jasa yang sewajarnya 
DE LEGA LATA

Jurnal Ilmu Hukum

FAKULTAS HUKUM UMSU
Perlindungan Hukum Terhadap...(Muhammad Ferdian) Volume 3 Nomor 2, Juli-Desember 2018, 166-184 DOI: https://doi.org/10.30596/dll.v3i2.3158

c. Belum terkondisinya masyarakat konsumen menjadi masyarakat yang mempunyai kemauan menuntut hak-haknya

d. Proses peradilan yang ruwet dan waktu yang berkepanjangan

e. Posisi konsumen yang lemah.

Faktor penyebab lemahnya konsumen dapat berasal dari sisi hukum, dapat pula dari kondisi social yang berkembang. Dari sisi hukum, garis besarnya adalah belum adanya kesadaran akan hak-haknya sebagai konsumen. Kelemahan ini sudah semakin tereliminasi seiring berkembangnya teknologi informasi yang menungkinkan setiap orang mengakses informasi dan memublikasikannya kepada siapa pun. Namun, kebebasan teknologi tersebut tidak lantas membuat konsumen sangat kuat, melainkan tetap harus berada pada koridor aturan kasus di luar sengketa konsumen itu sendiri (Intan Nur Rahmawati, dkk, 2014, h. 45).

Konsumen yang keberadaanya sangat tidak terbatas dengan strata yang sangat bervariasi menyebabkan produsen melakukan kegiatan pemasaran dan distribusi produk barang atau jasa dengan cara seefektif mungkin agar dapat mencapai konsumen yang sangat majemuk tersebut. Untuk semua itu cara pendekatan diupayakan sehingga mungkin menimbulkan berbagai dampak, termasuk keadaan yang menjurus pada tindakan yang bersifat negatif bahkan tidak terpuji yang berawal dari iktikad buruk. Dampak buruk yang lazim terjadi antara lain menyangkut kualitas, atau mutu barang, informasi yang tidak jelas bahkan menyesatkan pemalsuan dan sebagainya.

Bagi konsumen, informasi tentang barang dan atau jasa merupakan kebutuhan pokok, sebelum ia menggunakan sumber dananya (gaji, upah, honor atau apa pun nama lainnya) untuk mengadakan transaksi konsumen tentang jasa tersebut. Dengan transaksi konsumen dimaksudkan diadakannya hubungan hukum (jual beli, sewa-menyewa, pinjam-meminjam, dan sebagainya) tentang produk konsumen dengan pelaku usaha itu.

Informasi-informasi tersebut meliputi antara lain tentang ketersediaan barang atau jasa yang dibutuhkan masyarakat konsumen, tentang kualitas produk, keamanannya, harga, tentang berbagai persyartaan dan atau cara memperolehnya, tentang jaminan atau garansi produk, persediaan suku cadang, tersedianya pelayanan purna-jual, dan hal lain-lain berkaitan dengan itu (Az. Nasution, 2011,h. 55). Informasi tersebut dapat diperoleh dari keterangan atau bahan-bahan, lisan dan tertulis para pelaku usaha yang berkaitan.

Pada prinsispnya Balai Pom setempat atau daerah atau kabupaten kota baru membuka LOKA Pom yang tersebar di 40 kota di seluruh Indonesia. LOKA Pom selalu melakukan sampling obat dan juga mengawasi lengkap atau tidaknya label obat, sebagai contoh:

a. Obat bebas

Obat bebas merupakan obat yang mudah dijumpai, baik di toko obat maupun di apotek tanpa harus menggunakan resep dokter. Zat aktif yang terkandung didalmnya relatif aman dan memiliki efek samping rendah, selama dikonsumsi sesuai dengan petunjuk dan dosis yang ssuai dengan kemasan. Obat ini ditandai dengan lingkaran berwarna Hijau, dimana obat tersebut diperhatikan sangat lengkap baik etiket maupun brosurnya, lengkap dengan nama, nama dagang, nama generik, dosis, komposisi, nama pabrik, tanggal pembuatan dan tanggal 
DE IEGA LATA

Jurnal Ilmu Hukum

FAKULTAS HUKUM UMSU
Perlindungan Hukum Terhadap...(Muhammad Ferdian)

Volume 3 Nomor 2, Juli-Desember 2018, 166-184 DOI: https://doi.org/10.30596/dll.v3i2.3158

kadaluarsa, indikasi maupun perhatian-perhatian.

b. Obat bebas terbatas

Obat bebas terbatas ditambahi dengan peringatan, karena obat bebas terbatas memiliki peraturan yang lebih ketat dari obat bebas, dimana obat bebas terbatas mengandung zat yang keras sehingga pengawasannya lebih ketat. Obat ini ditandai dengan lingkaan berwana biru.

c. Obat keras

Obat ini mempunyai peraturan sendiri, dimana obat keras ini tidak boleh mencantumkan indikasinya, (baik dalam kotak, maupun stripnya) karena indikasi obat keras hanya boleh diketahui oleh dokter. Obat ini tidak boleh dibeli sembarangan, karena harus dibeli dengan resep dokter. Obat keras terbagi dua, yaitu obat psikotoprika dan narkoba. Obat ini ditandai dengan lingkaran berwarna merah dan ada huruf K didalamnya. Obat keras harus di tambahi dengan peringatan penandaan "tidak bisa dibeli sembarangan".

Menurut Peraturan Badan Pengawas Obat dan Makanan Nomor 12 Tahun 2018 Tentang Organisasi dan Tata Kerja Unit Pelaksana Teknisdi Lingkungan Badan pengawas Obat dan Makanan pasal 36, yaitu:

LOKA pom mempunyai tugas melakukan inspeksi dan sertifikasi sarana/fasilitas produksi dan/atau distribusi obat dan Makanan dan sarana/fasilitas pelayanan kefarmasian, sertifikasi produk, pengambilan contoh (sampling), dan pengelolaan komunikasi, informasi, edukasi, pengaduan masyarakat, dan koordinasi dan kerja sama di bidang pengawasan obat dan makanan, serta pelaksanaan urusan tata usaha dan rumah tangga.

Jika tidak berhati-hati dalam memilih produk barang/jasa yang diinginkan, konsumen hanya akan menjadi objek esploitasi dari pelaku usaha yang tidak bertanggung jawab. Tanpa disadari, konsumen menerima begitu saja barang/jasa yang dikonsumsinya. Perkembangan perekonomian, perdagangan, dan perindustrian yang kian hari kian meningkat telah memberikan kemanjaan yang luar biasa kepada konsumen karena ada beragam variasi produk barang dan jasa yang bisa dikonsumsi.

Perkembangan perekonomian tersebut membuat hubungan yang saling membutuhkan antara konsumen dengan pelaku usaha, para konsumen memerlukan barang/jasa untuk memenuhi hajat hidup mereka, sedangkan pelaku usaha yang memerlukan konsumen untuk menggunakan barang/jasa yang mereka miliki. Kondisi seperti ini memerlukan seperangkat kaidah hukum untuk menjaga hubungan baik antara pihak konsumen dan pelaku usaha, juga untuk menjauhkan dari kerugian antara kedua belah pihak.

Pembentukan Undang-Undang Perlindungan Konsumen tersebut tidak terlepas dari dinamika Politik Indonesia, yaitu pada saat itu iklim politik yang lebih demokratis ditandai dengan gerakan reformasi yang dikomadai oleh para mahasiswa. Gerakan yang diawali dengan adanya pergantian Presiden dari Soeharto kepada B.J Habibie. Dengan kehidupan yang lebih demokratis mulai diperjuangkan dan salah satu hasilnya adalah terbentuknya Undang-Undang Perlindungan Konsumen (UUPK)

UUPK ini dibuat untuk melindungi kepentingan konsumen dalam mengonsumsi barang 
DE LEGA LATA

Jurnal Ilmu Hukum

FAKULTAS HUKUM UMSU
Perlindungan Hukum Terhadap...(Muhammad Ferdian) Volume 3 Nomor 2, Juli-Desember 2018, 166-184 DOI: https://doi.org/10.30596/dll.v3i2.3158

dan/atau jasa, maka pemerintah mengeluarkan kebijakan pengaturan hak-hak konsumen yang diatur dalam UUPK ini. Pembentukan UUPK ini sebagai wujud implementasi cita-cita pendiri Negara ini tertuang di dalam Undang-Undang Dasar 1945 yaitu menjunjung tinggi kesejahteraan masyarakat sehingga konstitusi ekonomi mengandung ide Negara sejahtera (Aulia muthiah, 2018, h. 26-27).

Perlindungan hukum bagi konsumen adalah dengan melindungi hak-hak konsumen. Walaupun sangat beragam, secara garis besar hak-hak konsumen dapat dibagi dalam tiga hak yang menjadi prinsip dasar, yaitu:

a. Hak yang dimaksudkan untuk mencegah konsumen dari kerugian, baik kerugian personal, maupun kerugian harta kekayaan.

b. Hak untuk memperoleh barang dan/atau jasa dengan harga wajar; dan

c. Hak untuk memperoleh penyelesaian yang patut terhadap permasalahan yang dihadapi (Abdul Halim Barkatullah, 2010: 25).

Apabila konsumen benar-benar akan dilindungi, maka hak-hak konsumen harus dipenuhi, baik oleh Negara maupun pelaku usaha, karena pemenuhan hak-hak konsumen tersebut akan melindungi kerugian konsumen dari berbagai aspek. Dalam Pasal 2 UUPK, dinyatakan bahwa perlindungan hukum bagi konsumen diselenggarakan sebagai usaha bersama berdasarkan 5 (lima) prinsip dalam pembangunan nasional, yaitu: (Abdul Halim Barkatullah, 2010, h. 26).

a. Prinsip manfaat, dimaksudkan untuk mengamanatkan bahwa segala upaya dalam penyelenggaraan perlindungan hukum bagi konsumen harus memberi manfaat sebesar-besarnya bagi kepentingan konsumen dan pelaku usaha secara keseluruhannya.

b. Prinsip keadilan. Dimaksudkan agar partisipasi seluruh rakyat dapat diwujudkan secara maksimal dan memberikan kesempatan kepada konsumen dan pelaku usaha untuk memperoleh haknya dan melaksanakan kewajibannya secara adil.

c. Prinsip keseimbangan. Dimaksudkan untuk memberikan keseimbangan antara kepentingan konsumen, pelaku usaha, dan pemerintah.

d. Prinsip keamanan dan keselamatan konsumen. Dimaksudkan untuk memberi jaminan atas keamanan dan keselamatan kepada konsumen dalam penggunaan, pemakaian, dan pemanfaatan barang dan/atau jasa yang digunakan.

e. Prinsip kepastian hukum. Dimaksudkan agar baik pelaku usaha maupun konsumen mentaati hukum dan memperoleh keadilan dalam penyelenggaraan perlindungan hukum bagi konsumen, dimana Negara dalam hal ini turut menjamin adanya kepastian hukum tersebut.

Melalui kelima asas tersebut, terdapat komitmen untuk mewujudkan tujuan perlindungan hukum bagi konsumen, yaitu:

a. Meningkatkan kesadaran, kemampuan dan kemandirian konsumen untuk melindungi diri.

b. Mengangkat harkat dan martabat konsumen dengan cara menghindarkannya diri akses negative pemakaian barang dan/atau jasa. 
DEIFGA IATA

Jurnal Ilmu Hukum

FAKULTAS HUKUM UMSU
Perlindungan Hukum Terhadap...(Muhammad Ferdian) Volume 3 Nomor 2, Juli-Desember 2018, 166-184 DOI: https://doi.org/10.30596/dll.v3i2.3158

c. Meningkatkan pemberdayaan konsumen dalam memilih, menentukan, dan menuntut hak-haknya sebagai konsumen.

d. Menciptakan system perlindungan konsumen yang mengandung unsur kepastian hukum dan keterbukaan informasi serta akses untuk mendapatkan informasi.

e. Menumbuhkan kesadaran pelaku usaha mengenai pentingnya perlindungan hukum bagi konsumen, sehingga tumbuh sikap yang jujur dan bertanggung jawab dalam berusaha.

f. Meningkatkan kualitas barang dan/atau jasa yang menjamin kelangsungan usaha produksi barang dan/atau jasa, kesehatan, kenyamanan, keamanan, dan keselamatan konsumen.

Mewujudkan tujuan perlindungan hukum bagi konsumen, Negara bertanggung jawab atas pembinaan dan penyelenggaraan perlindungan hukum bagi konsumen. Pembinaan dan penyelenggaraan perlindungan hukum bagi konsumen dilakukan melalui upaya-upaya sebagai berikut:

a. iklim usaha dan tumbuhnya hubungan yang sehat antara pelaku usaha dan konsumen;

b. Berkembangnya lembaga perlindungan hukum bagi konsumen baik oleh Negara atau swadaya masyarakat;

c. Meningkatnya kualitas sumber daya manusia serta meningkatnya kegiatan penelitian dan pengembangan di bidang perlindungan hukum bagi konsumen.

Tujuan penyelenggaraan, pengembangan dan pengaturan perlindungan hukum bagi konsumen yang direncanakan adalah untuk meningkatkan martabat dan kesadaran konsumen, serta secara tidak langsung mendorong pelaku usaha di dalam menyelenggarakan kegiatan usaha dengan penuh rasa tanggung jawab.

Penerapan peraturan hukum perlindungan konsumen seringkali mereflleksikan ketidakseimbangan kekuatan antara pelaku usaha dan konsumen. Secara historis, konsumen dianggap pihak yang lebih lemah dalam transaksi bisnis sehingga aturan-aturan serta regulasi khusus dikeluarkan untuk melindungi kepentingan konsumen (Abdul Halim Barkatullah, 2010: 27).

Secara historis mengenai hak-hak dasar konsumen pertama kali dikemukakan oleh presiden Amerika Serikat John F.Kennedy saat menyampaikan pidato revolusioner di depan kongres (US Congress) pada tanggal 15 Maret 1962 tentang hak konsumen, yang diberi judul A Special Massage of Protection the Costumer Interest. Dalam masyarakat internasional lebih dikenal dengan "Declaration of Consumer Right".

Presiden John F.Kennedy menyebut empat hak dasar konsumen atau the four consumer basic right, yaitu:

a. The right to safety (hak atas keamanan)

b. The right to choose (hak untuk memilih)

c. The right to be informed (hak mendapatkan konfirmasi)

d. The right to be heard (hak untuk didengar pendapatnya) (Aulia Muthiah, 2018: 24).

Selain itu faktor yang juga menjadi pendorong terbentuknya UUPK adalah perkembangan system perdagangan Global yang dibentuk dalam rangka World Trade 
DEIFGA LATA

Jurnal Ilmu Hukum

FAKULTAS HUKUM UMSU
Perlindungan Hukum Terhadap...(Muhammad Ferdian) Volume 3 Nomor 2, Juli-Desember 2018, 166-184 DOI: https://doi.org/10.30596/dll.v3i2.3158

Organization (WTO) dan juga gerakan Internasional Monetary Fund (IMF) dan program Bank Dunia keputusan Indonesia untuk meratifikasi perjanjian perdagangan dunia diikuti dengan dorongan terhadap pemerintah Indonesia di bidang perdagangan (Aulia Muthiah, 2018, h. 28).

Dengan terbentuknya UUPK ini konsumen juga diberikan kemudahan jika mendapat perlakuan yang tidak adil dari pelaku usaha atau konsumen dirugikan oleh pelaku usaha. UUPK mewajibkan adanya Badan Perlindungan Konsumen Nasional (BPKN) yang mempunyai fungsi memberikan saran dan pertimbangan kepada pemerintah dalam upaya mengembangkan perlindungan konsumen di Indonesia. Lembaga lainyang terbentuk setelah adanya UUPK ini adalah Lembaga Perlindungan Konsumen Swadaya Masyarakat (LPKSM), lembaga ini berfungsi untuk menyampaikan infoemasi dalam rangkan meningkatkan kesadaran atas hak-hak dan kewajiban dan mengajarkan kepada semua elemen masyrakat agar menjadi kknsumen cerdas dengan cara lebih berhati-hati dalam memilih setiap produk yang akan dikonsumsi (Aulia Muthiah, 2018, h. 30).

Selanjutnya UUPK ini juga mewajibkan terbentuknya Badan Penyelesaian Sengketa Konsumen (BPSK) lembaga ini berfungsi untuk mengawasi pelaku usaha, memberikan konsultasi kepada konsumen yang memerlukan perlindungan dari pelaku usaha nakal, serta membantu penyelesaian sengketa antara pelaku usaha dengan konsumen yang sifatnya non litigasi atau di luar pengadilan.

UUPK ini mempunyai judul Perlindungan Konsumen akan tetapi materinya lebih banyak membahas mengenai pelaku usaha dengan tujuan memberikan perlindungan terhadap konsumen. Hal ini disebabkan pada umumnya kerugian yang diderita oleh konsumen merupakan kibat perilaku dari pelaku usaha sehingga perlu diatur agar konsumen tidak selalu menjadi pihak yang dirugikan, namun jika kerugian telah dialami oleh konsumen maka dengan adanya UUPK diharapkan kerugian ini segera diganti oleh pelaku usaha, inilah keadilan yang diharapkan oleh konsumen. Jadi UUPK ini menekankan hak dan kewajiban pelaku usaha dengan konsumen, sehingga ketika kewajiban telah dilaksanakan maka pihak lainnya jga harus menunaikan haknya, demi terwujud keseimbangan para pihak pelaku ekonomi (Aulia Muthiah, 2018, h. 30).

Konsekuensi setiap pelaku usaha adalah harus memiliki tanggung jawab sosial yaitu kepedulian dan komitmen moral pelaku usaha terhadap kepentingan masyarakat terlepas dari kalkulasi untung dan rugi perusahaan. Tanggung jawab tersebut yakni tanggung jawab perusahaan terhadap kesejahteraan bagi lingkungan masyarakat. Pada hakikatnya, tanggung jawab sosial pelaku usaha terhadap konsumen merupakan kepentingan perusahaan untuk mewujudkan kepercayaan masyrakat. Jadi sesungguhnya pengaturan perlindungan konsumen tidak bertujuan untuk melemahkan usaha dan aktivitas pelaku usaha, tetapi sebaliknya tanggung jawab pelaku usaha memberikan kenyamanan kepada konsumen akan mampu mendorong tercapainya persaingan usaha yang sehat. Sehingga pelaku usaha diuntungkan dengan banyaknya konsumen, sedangkan konsumen akan merasa nyaman dengan ketersediaan barang dan/atau jasa yang berkualitas. 
DE LEGA LATA

Jurnal Ilmu Hukum

FAKULTAS HUKUM UMSU
Perlindungan Hukum Terhadap...(Muhammad Ferdian) Volume 3 Nomor 2, Juli-Desember 2018, 166-184 DOI: https://doi.org/10.30596/dll.v3i2.3158

Hubungan antara pelaku usaha dengan konsumen merupakan hubungan yang saling ketergantungan, berjalan secara berkelanjutan sehingga iktikad baik pelaku usaha dan konsumen saat diperlukan untuk menghindari kerugian yang mungkin terjadi kepada kedua belah pihak ini (Aulia Muthiah, 2018, h.31).

UUPK dirumuskan dengan mengacu pada filosofi pembangunan nasional bahwa pembangunan nasional termasuk pembangunan hukum yang memberikan perlindungan terhadap konsumen adalah dalam rangka membangun manusia Indonesia seutuhnya yang berlandaskan falsafah kenegaraan Republik Indonesia yaitu dasar Negara Pancasila dan konstitusi Negara UUD 1945.

Sebagaimana yang telah kita ketahui ketentuan Pasal 33 UUD 1945 tentang Perekonomian sosial yang isinya yaitu:

a. Perekonomian disusun sebagai usaha bersama berdasarkan atas asas kekeluargaan

b. Cabang-cabang produksi yang penting bagi Negara dan yang menguasai hajat hidup orang banyak dikuasai oleh Negara.

c. Bumi dan air dan kekayaan alam yang terkandung di dalamnya dikuasai oleh Negara dan dipergunakan untuk sebesar-besarnya kemakmuran rakyat.

Pasal 33 UUD 1945 ini sebagai dasar demokrasi ekonomi yang merupakan ketentuan imperative dalam pembentukan perundang-undangan di bidang ekonomi, karena dasar-dasar pemikiran dan perumusan Pasal 33 UUD 1945 mengatur tentang dasar-dasar system ekonomi atau tata susunan perekonomian dan kegiatan-kegiatan perekonomian yang dikehendaki (Aulia Muthiah, 2018: 32).

UUPK menyebutkan bahwa Pemerintah bertanggung jawab atas pembinaan penyelenggaraan perlindungan konsumen yang menjamin diperolehnya hak konsumen dan pelaku usaha serta dilaksanakannya kewajiban konsumen dan pelaku usaha. Pada dasarnya pembuat dan pelaksanaan politik hukum perlindungan konsumen itu adalah pemerintah, jadi tanggung jawab penyelenggaran perlindungan konsumen adalah pemerintah. Akan tetapi bukan berarti masyarakat tidak terlibat dalam penyelenggaraan perlindungan konsumen. Jadi UUPK dimaksudkan menjadi landasan hukum yang kuat bagi pemerintah dan lembaga perlindungan swadaya masyarakat untuk melakukan upaya pemberdayaan konsumen melalui pembinaan dan pendidikan konsumen.

UUPK menjunjung tinggi Hak asasi manusia (selanjutnya disingkat dengan HAM) serta menjamin hak warga Negara bersamaan kedudukannya di depan hukum, sehingga pemerintah harus wajib menjunjung hukum dengan sebaik-baiknya tanpa harus ada perbedaan. Akan tetapi penerapan hukum dan penegakannya di Indonesia masih jauh dari sempurna. Kelemahan utama bukan pada sistem hukum dan produk hukum, akan tetapi pada penegakan hukum. Harapan masyarakat untuk memperoleh jaminan dan kepastian hukum masih sangat terbatas. Sehingga jika kita perhatikan bahwa penegakan dan pelaksanaan hukum belum berjalan sesuai dengan prinsip-prinsip keadilan dan kebenaran, termasuk pelaksanaan dan penegakan hukum perlindungan konsumen (Aulia Muthiah, 2018, h. 34).

Tujuan penyelenggaraan, pengembangan dan pengaturan perlindugan konsumen yang 
DE LEGA LATA

Jurnal Ilmu Hukum

FAKULTAS HUKUM UMSU
Perlindungan Hukum Terhadap...(Muhammad Ferdian) Volume 3 Nomor 2, Juli-Desember 2018, 166-184 DOI: https://doi.org/10.30596/dll.v3i2.3158

direncanakan adalah untuk meningkatkan martabat dan kesadaran konsumen, dan secara tidak langsung mendorong pelaku usaha dalam menyelenggarakan kehgiatan usahanya dengan penuh rasa tanggung jawab. Perlindungan konsumen akan ditemukan juga istilah hukum konsumen, meskipun belum terdapat aturan mengenai perbedaan atau keharusan menggunakan istilah baku dari keduanya, para akademisi lebih mengacu kepada istilah yang digunakan oleh ahli hukum konsumen dari Belanda Hondius yang menggunakan istilah hukum konsumen. Sampai saat ini belum banyak pakar yang memberikan perbedaan antara kedua jenis istilah tersebut jika mengacu pada UUPK maka yang digunakan adalah "perlindungan konsumen" sedangkan dalam hal memberikan perlindungan terhadap konsumen dalam perspektif aturan hukumnya, dapat digunakan istilah hukum perlindungan konsumen (Aulia Muthiah, 2018, h. 39).

Hukum konsumen dan hukum perlindungan konsumen pada hakikatnya adalah sama dan tidak perlu dibedakan satu dengan yang lainnya. Karena kedua hal ini bertujuan untuk memberikan pengaturan gubungan yang seimbang antara pelaku usaha dengan konsumen supaya hak-hak konsumen terlindungi tanpa harus melupakan kewajibannya. Bertitik tolak dari penetapan asas-asas hukum perlindungan konsumen di atas tersebut maka hukum perlindungan konsumen dapat diartikan sebagai serangkaian norma yang bertujuan melindungi kepentingan konsumen atas pemenuhan barang dan atau jasa yang didasarkan kepada manfaat, keadilan, keseimbangan, keamanan, keselamatan konsumen, serta kepastian hukum (Aulia Muthiah, 2018, h. 41).

\section{Akibat Hukum Bagi Produk Obat Yang Tidak Memenuhi Standar Pelabelan}

Sesuai dengan tahapan pembangunan nasional, terdapat kemajuan yang cukup besar di bidang teknologi, industri, dan perdagangan. Sementara dibalik itu, kedudukan konsumen masih sangat lemah. Pembangunan yang dilakukan membawa pula akibat sampingan yang semakin kompleks yang memerlukan penanganan serius, khususnya masalah perlindungan konsumen. Kebutuhan hukum dan perkembangan kesadaran hukum dalam kehidupan bermasyarakat dan bernegara senantiasa berkembang dinamis sejalan dengan perkembangan pembangunan bangsa disegala bidang. Oleh karena itu, pembinaan hukum harus mampu mengarahkan dan menampung kebutuhan-kebutuhan hukum sesuai dengan tingkat kemajuan dan pembangunan disegala bidang, sehingga tercapai ketertiban, keadilan, dan kepastian hukum yang mengarah kepada peningkatan kesejahteraan masyarakat (Adrian sutedi, 2008, h. $31)$.

Hukum senantiasa berkembang dinamis. Bahwa hukum yang baik adalah hukum yang sesuai dengan hukum hidup (the living law) dalam masyarakat, tentu sesuai pula atau merupakan pencerminan dari nilai-nilai yang berlaku dalam masyarakat yang bertujuan untuk menjadi dasar dan memelihara ketertiban, keadilan, dan kesejahteraan masyarakat. Hukum juga berfungsi mengabdi kepada masyrakat, dalam hal ini mengatur tata tertib masyarakat, menjaga agar perilaku masyarakat sesuai dengan peraturan hukum, sehingga kepentingankepentingannya dilindungi hukum. Jika perkembangan kepentingan masyarakat bertambah, 
DE IEGA LATA

Jurnal Ilmu Hukum

FAKULTAS HUKUM UMSU
Perlindungan Hukum Terhadap...(Muhammad Ferdian) Volume 3 Nomor 2, Juli-Desember 2018, 166-184 DOI: https://doi.org/10.30596/dll.v3i2.3158

maka harus diikuti pula dengan perkembangan hukum, sehingga kebutuhan hukum dalam kehidupan masyarakat dan bernegara sejalan dengan perkembangan pembangunan.

Terlebih lagi dalam era globalisasi, maka hukum harus dapat mendukung tumbuhnya dunia usaha sehingga mampu menghasilkan beraneka ragam barang dan/atau jasa yang memiliki kandungan teknologi yang dapat meningkatkan kesejahteraan masyarakat banyak dan sekaligus mendapatkan kepastian atas barang dan/atau jasa yang diperoleh dari perdagangan tanpa mengakibatkan kerugian pada konsumen. Kerugian-kerugian yang diderita konsumen merupakan akibat kurangnya tanggung jawab pelaku usaha terhadap konsumen (Adrian sutedi, 2008, h. 32).

Tujuan penyelenggaraan, pengembangan, dan pengaturan perlindungan konsumen yang di rencanakan adalah untuk meningkatkan martabat dan kesadaran konsumen dan secara tidak langsung mendorong pelaku usaha di dalam menyelenggarakan kegiatan usaha dengan penuh rasa tanggung jawab. Pengaturan perlindungan konsumen dilakukan dengan: (Adrian sutedi, 2008, h. 63)

a. Menciptakan sistem perlindungan konsumen yang mengandung akses dan informasi, serta menjamin kepastian hukum;

b. Melindungi kepentingan konsumen pada khususnya dan kepentingan seluruh pelaku usaha;

c. Meningkatkan kualitas barang dan pelayanan jasa;

d. Memberikan perlindungan kepada konsumen dari praktik usaha yang menipu dan menyesatkan

e. Memadukan penyelanggaraan, pengembangan, dan pengaturan perlindungan konsumen dengan bidang-bidang perlindungan pada bidang-bidang lainnya.

Tanggung jawab produk (product liability) diartikan sebagai tanggung jawab atas kerugian yang diakibatkan oleh pemakaian atau penggunaan suatu produk atau yang berkaitan dengan barang-barang konsumsi. Termasuk dalam pengertian produk tersebut tidak sematamata suatu produk yang sudah jadi secara keseluruhan, tetapi juga termasuk komponen suku cadang (Adrian sutedi, 2008, h. 64).

Alasan-alasan mengapa prinsip tanggung jawab mutlak (strict liability) diterapkan dalam hukum tentang product liability adalah sebagai berikut: (Adrian sutedi, 2008, h. 68).

a. Di antara korban/ konsumen di satu pihak dan produseb di lain pihak, beban kerugian (risiko) seharusnya ditanggung oleh pihak yang memproduksi/mengeluarkan barangbarang cacat/berbahaya tersebut di pasaran.

b. Dengan menempatkan/mengedarkan barang-barang di pasaran, berarti produsen menjamin bahwa barang-barang tersebut aman dan pantas untuk dipergunakan dan bimana terbukti tidak demekian, dia harus bertanggung jawab.

c. Sebenarnya tanpa menerapkan prinsip tanggung jawab mutlak pun produsen yang melakukan kesahalan tersebut dapat dituntut melalui proses penuntutan beruntun, yaitu konsumen kepada pedagang eceran, pengecer kepada grosir, grosir kepada distributor, distributor kepada agen, agen kepada produsen. Penerapan strict liability dimaksudkan untuk menghilangkan proses yang panjang ini. 
Jurnal Ilmu Hukum

FAKULTAS HUKUM UMSU
Perlindungan Hukum Terhadap...(Muhammad Ferdian) Volume 3 Nomor 2, Juli-Desember 2018, 166-184 DOI: https://doi.org/10.30596/dll.v3i2.3158

Hukum tentang product liability, pihak korban/konsumen yang akan menuntut kompensasi pada dasarnya hanya diharuskan menunjukkan tiga hal: pertama, bahwa produk tersebut telah cacat pada waktu diserahkan oleh produsen; kedua, bahwa cacat tersebut telah menyebabkan atau turut menyebabkan kerugian/kecelakaan; ketiga, adanya kerugian. Namun, juga diakui secara umum bahwa pihak korban/konsumen harus menunjukkan bahwa pada wajtu terjadinta kerugian, produk tersebut pada prinsipnya berada dalam keadaan seperti waktudiserahkan oleh produsen (artinya tidak ada modifikasi-modifikasi).

Meskipun sistem tanggung jawab pada product liability berlaku prinsip strict liability, pihak produsen dapat membebaskan diri dari tanggung jawabnya, baik untuk seleruhnya atau untuk sebagian. Hal-hal yang dapat membebaskan tanggung jawab produsen tersebut adalah sebagai berikut: (Adrian sutedi, 2008, h. 70).

a. Jika produsen tidak mengedarkan produknya (put into circulation).

b. Cacat yang menyebabkan kerugian tersebut tidak ada pada saat produk diedarkan oleh produsen atau terjadinta cacat tersebut baru timbul kemudian.

c. Bahwa produk tersebut tidak dibuat oleh produsen baik untuk dijual atau diedarkan untuk tujuan ekonomis maupun dibuat atau diedarkan dalam rangka bisnis.

d. Bahwa terjadinya cacat pada produk tersebut akibat keharusan memenuhi kewajiban yang ditentukan dalam peraturan yang dikeluarkan oleh pemerintah.

e. Bahwa secara ilmiah dan teknis ( state of scientific an technical knowledge, state oof art defense ) pada saat produk diedarkan tidak mungkin cacat.

f. Dalam hal produsen dari suatu komponen, bahwa cacat tersebut disebabkan oleh desain dari produk itu sendiri di mana komponen telah dicocokkan atau disebabkan kesalahan pada petunjuk yang diberikan oleh pihak produsen tersebut.

g. Bila pihak yang menderita kerugian atau pihak ketiga turur menyebabkab terjadinya kerugian tersebut ( contributory negligence)

h. Kerugian yang terjadi diakibatkan oleh Acts of God atau force majeur.

Produsen maupun penjual (penyalur) berkewajiban menjamin kualitas produk yang mereka pasarkan. Yang dimaksud dengan jaminan ( warranty) atas kualitas produk ini adalah suatu jaminan atau generasi bahwa barang-barang yang dibeli akan sesuai dengan standar kualitas produk tertentu. Jika standard itu tidak dipenuhi, maka pembeli atau konsumen dapat memperoleh ganti rugi dari pihak produsen/penjual.

Jaminan atas kualitas produk dapat dibedakan atas dua macam, yaitu sebagai berikut: (Adrian sutedi, 2008, h. 75)

a. Express warranty (jaminan secara tegas)

Express warranty adalah suatu jaminan atas kualitas produk, baik dinyatakan secara lisan maupun tertulis. Dengan adanya express warranty ini, berarti produsen sebagai pihak yang menghasilkan barang (produk) dan juga penjual sebagai pihak yang menyalurkan barang atau produk dari produsen atau pembeli bertanggung jawab untuk melaksanakan kewajibannya terhadap adanta kekurangan atau kerusakan dalam produk yang dipasarkan. Dalam hal demikian, konsumen dapat mengajukan tuntutannya berdasarkan adanya wanprestatie.

b. Implied warranty 
DE LEGA LATA

Jurnal Ilmu Hukum

FAKULTAS HUKUM UMSU
Perlindungan Hukum Terhadap...(Muhammad Ferdian) Volume 3 Nomor 2, Juli-Desember 2018, 166-184 DOI: https://doi.org/10.30596/dll.v3i2.3158

Implied warranty adalah suatu jaminan yang dipaksakan oleh Undang-Undang atau hukum, sebagai akibat dari penjualan barang-barang dalam keadaan tertentu. Jadi, dengan implied warranty, dianggap bahwa jaminan ini selalu mengikuti barang yang dijual, kecuali dinyatakan lain. Misalnya, kewajiban penjual untuk menanggung adanya cacat tersembunyi (verborgen gebrek) pada barang yang dijualnya, meskipun ia tidak mengetahui adanya cacat tersebut, kecuali jika ia dalam keadaan demikian telah minta diperjanjikan bahwa ia tidak diwajibkan menanggung suatu apa pun (Pasal 1506 KUH Perdata).

Konsumen dan pelaku usaha adalah menjadi subjek pada kajian perlindungan konsumen selain konsumen dan pelaku usaha ada satu hal menarik yang harus dibahas yaitu tentang produk. Produk merupakan suatu objek transaksi antara pelaku usaha dengan konsumen produk dapat berupa batrang dan jasa.

Menurut pasal 1 angka 4 UUPK produk yang berupa barang adalah "Barang adalah setiap benda, baik berwujud maupun tidak berwujud, baik bergerak maupun tidak bergerak, dapat dihabiskan maupun tidak dapat dihabiskan, yang dapat untuk diperdagangkan, dipakai, dipergunakan, atau dimanfaatkan oleh konsumen". Adapun tentang produk berupa jasa menurut UUPK pada pasal 1 angka 5 menyatakan bahwa "jasa adalah setiap layanan yang berbentuk pekerjaan atau prestasi yang disediakan bagi masyarakat untuk dimanfaatkan oleh konsumen"

Pemakaian teknologi yang makin baik, di satu sisi memungkinkan produk mampu membuat produk beraneka macam jenis, bentuk, kegunaan, maupun kualitasnya sehingga pemenuhan kebutuhan konsumen dapat terpenuhi lebih luas, lengkap, cepat, dan menjangkau bagian tebesar lapisan masyarakat. Akan tetapi, di sisi lain penggunaan teknologi memungkinkan dihasilkannya produk yang tidak sesuai dengan persyaratan keamanan dan keselamatan pemakai sehingga menimbulkan kerugian kepada konsumen (Janus Sidabalok, 2014, h. 15).

Upaya pemerintah untuk melindungi konsumen dari produk yang merugikan dapat dilaksanakan dengan cara mengatur, mengawasi, serta mengendalikan produksi, distribusi, dan peredaran produk sehingga konsumen tidak dirugikan, baik kesehatannya maupun keuangannya.

Berdasarkan tujuan yang ingin dicapai dan kebijakan yang akan dilaksanakan, maka langkah-langkah yang dapat ditempuh pemerintah adalah: (Janus Sidabalok, 2014, h. 19)

a. Registrasi dan penilaian

b. Pengawasan produksi

c. Pengawasan distribusi

d. Pembinaan dan pengawasan usaha

e. Peningkatan dan pengembangan prasarana dan tenaga.

Peranan pemerintah sebagaimana telah disebutkan di atas maka dikategorikan sebagai pernana yang berampak jangka panjang sehingga perly dilakukan secara kontinu memberikan penerangan, penyuluhan, dan pendidikan bagi semua pihak. Dengan demikian, tercipta 
DE LEGA LATA

Jurnal Ilmu Hukum

FAKULTAS HUKUM UMSU
Perlindungan Hukum Terhadap...(Muhammad Ferdian)

Volume 3 Nomor 2, Juli-Desember 2018, 166-184 DOI: https://doi.org/10.30596/dll.v3i2.3158

lingkungan usaha yang sehat dan berkembangnya pengusaha yang bertanggung jawab. Termasuk di sisni menciptakan pasar yang kompetitif dengan berangsur-angsur menghilangkan monopoli dan proteksi. Dalam jangka pendek, pemerintah dapat menyelesaikan secara langsung dan cepat masalah-masalah yang timbul.

Posisi ketiga pihak terkait, yaitu produsen-pelaku usaha, konsumen, dan pemerintah, masing-masing adalah mandiri sehingga perlu diatur dengan baik untuk mencapai keserasian dan keharmonisan dalam kegiatan ekonomi. Pemerintah ditugaskan untuk mengatur hal tersebut berdasarkan Pasal 33 UUD Negara Republik Indonesia tahun 1945, dapat melaksanakannya melalui pembuatan peraturan dan pengawasan pelaksanaan peraturanperaturan itu.

Peraturan-peraturan yang dimaksud adalah peraturan yang juga mengikat pemerintah sehingga tidak muncul kolusi antara pengusaha dan pemerintah yang dapat merugikan konsumen (Janus Sidabalok, 2014, h. 20). Berkaitan dengan produk, cacat dapat ditemukan dalam tiga tahapan klasifikasi menurut tahap-tahap produksi, yaitu kerusakan produk, kerusakan desain, dan pemberian informasi yang tidak memadai. Produk dapat dikategorikan cacat apabila produk itu rusak, atau desainnya tidak sesuai dengan seharusnya, atau informasi yang menyertai produk itu tidak memadai.

Apabila ditemukan obat yang tidak memenuhi standar pelabelan yang sudah disyaratkan, maka BPOM pusat akan memberikan sanksi administratif berupa peringatan, dan pemberentian kegiatan. Untuk menghindari kemungkinan adanya produk yang cacat atau berbahaya, maka perlu di tetapkan standard minimal yang harus dipedomani dalam berproduksi untuk menghasilkan produk yang yang layak dan aman untuk dipakai. Usaha inilah yang disebut dengan standarisasi.

Menurut Gandi, standarisasi adalah proses penyusunan dan penerapan aturan-aturan dalam pendekatan secara teratur bagi kegiatan tertentu untuk kemanfaatan dan dengan kerja sama dari semua pihak yang berkepentingan, khususnya untuk meningkatkan penghematan menyeluruh secara optimum dengan memperhatikan kondisi fungsional dan persyaratan keamanan. Hal ini didasarkan pada konsolidasi hasil (ilmu) teknologi dan pengalaman.

Dengan demikian, standarisasi berfungsi membantu menjembatani kepentingan konsumen dan produsen-pelaku usaha dengan menetapkan standard produk yang tepat dapat memenuhi kepentingan dan mencerminkan aspirasi kedua belah pihak. Dengan adanya standarisasi produk ini akan memberi manfaat yang optimum pada konsumen dan produsen, tanpa mengurangi hak milik dari konsumen (Janus Sidabalok, 2014, h. 16).

Standarisasi ini berkaitan erat dengan keamanan dan keselamatan konsumen, yaitu berkaitan dengan kelayakan suatu produk untuk dipakai atau dikonsumsi. Barang yang tidak memenuhi syarat mutu, khususnya obat dan makanan, dapat menimbulkan malapetaka bagi konsumen. Selain merugikan konsumen dari segi finansial, barang yang tidak memenuhi syarat mutu tersebut dapat pula mengancam keamanan dan keselamatan masyarakat umum.

Standarisasi ini bertujuan untuk menekan angka tentang cacat produk. Untuk menghindari kemungkinan adanya cacat produk maka ditetapkan standarisasi minimal yang 
DE IEGA LATA

Jurnal Ilmu Hukum

FAKULTAS HUKUM UMSU
Perlindungan Hukum Terhadap...(Muhammad Ferdian) Volume 3 Nomor 2, Juli-Desember 2018, 166-184 DOI: https://doi.org/10.30596/dll.v3i2.3158

harus dipedomani dalam memproduksi suatu barang. Suatu produk dapat dikatakan cacat apabila produk itu rusak, atau desainnya tidak sesuai dengan yang seharusnya, atau karena informasi yang menyertai produk tidak sesuai. Sehingga kecacatan pada suatu produk dapat membahayakan konsumen.

Standarisasi produk ini berkaitan erat dengan keamanan dan keselamatan konsumen yaitu berkaitan dengan kelayakan suatu produk untuk dipakai atau dikonsumsi, produk yang tidak memenuhi syarat mutu, khususnya obat, dapat menimbulkan malapetaka bagi konsumen. Selain merugikan konsumen dari segi finansial, barang yang tidak memenuhi syarat mutu tersebut dapat pula mengancam keamanan dan keselamatan masyarakat umum. Manfaat standarisasi produk adalah:

a. Pemakaian bahan secara ekonomi, perbaikan mutu, penurunan ongkos produksi, dan penyerahan yang cepat.

b. Penyederhanaan pengiriman dan penanganan barang.

c. Perdagangan yang adil, peningkatan kepuasan langganan.

d. Interchangeability komponen kemungkinan subcontracting

e. Keselamatan kehidupan dan harta.

Jadi tujuan utama adanya standarisasi produk adalah untuk memberikan gambaran kepada para pelaku usaha supaya memproduksi suatu barang lebih berhati-hati karena dikhawatirkan produk yang sudah diproduksi ini akan membahayakan keselamatan para konsumen yang mengonsumsinya.

Ketentuan-ketentuan yang merupakan kewajiban yang harus dipenuhi diperhatikan oleh pelaku usaha obat yang dalam Undang-Undang Republik Indonesia Nomor 36 Tahun 2009 Tentang Kesehatan diatur dalam Pasal 106 menyebutkan:

a. Sediaan farmasi dan alat kesehatan hanya dapat diedarkan setelah mendapat izin edar;

b. Penandaan dan informasi sediaan farmasi dan alat kesehatan harus memenuhi persyaratan objektivitas dan kelengkapan serta tidak menyesatkan;

c. Pemerintah berwenang mencabut izin edar dan memerintah penarikan dari peredaran sediaan farmasi dan alat kesehatan yang telah memperoleh izin edar, yang kemudian terbukti tidak memenuhi persyaratan mutu dan atau keamanan dan atau kemanfaatan, dapat disita dan dirumuskan sesuai dengan ketentuan Peraturan PerundangUndangan.

Lebih lanjut diatur dalam peraturan pemerintah republik Indonesia No. 51 Tahun 2009 Tentang Pekerjaan Kefarmasian Pasal 14 menyebutkan:

a. Setiap fasilitas distribusi atau penyalurkan sediaan farmasi berupa obat harus memiliki seorang Apoteker sebagai penanggung jawab;

b. Apoteker sebagai penanggung jawab sebagaimana dimaksud pada ayah (1) dapat dibantu oleh apoteker pendaping dan atau tenaga teknis kefarmasian;

Lebih lanjut lagi disebutkan dalam Pasal 16 PP No. 51 Tahun 2009 Tentang Pekerjaan Kefarmasian ini yaitu: 
Jurnal Ilmu Hukum

FAKULTAS HUKUM UMSU
Perlindungan Hukum Terhadap...(Muhammad Ferdian) Volume 3 Nomor 2, Juli-Desember 2018, 166-184 DOI: https://doi.org/10.30596/dll.v3i2.3158

a. Dalam melakukan pekerjaan kefarmasian, apoteker sebagiamana dimaksud dalam Pasal 14 harus menetapkan standard prosedur operasional.

b. Standar prosedur operasional harus dibuat secara tertulis dan diperbaharui secara terus menerus sesuai dengan perkembangan ilmu pengetahuan dan teknologi dibidang farmasi.

Ketentuan-ketentuan di atas dapat dilihat bahwa setiap orang atau pelaku usaha obat wajib memiliki izin untuk memproduksi atau mengedarkan produknya dan harus memiliki keahlian dibidang apoteker atau dibantu oleh seorang apoteker secara mengikuti perkembangan ilmu pengetahuan dan teknologi dibidang farmasi.

\section{KEIMPULAN DAN SARAN \\ Kesimpulan}

Perlindungan hukum terhadap konsumen yang membeli obat yang tidak sesuai dengan label merupakan kepentingan masyarakat, oleh karena itu menjadi harapan bagi semua masyarakat di setiap Negara yang ada di dunia untuk dapat mewujudkannya. Wujud dari perlindungan konsumen adalah dari berbagai hubungan yang satu sama lain saling terkait. Hubungan antara konsumen, pelaku usaha dan pemerintah. Yang dimana hubungan antara pelaku usaha dengan konsumen merupakan hubungan yang terus menerus dan berkesinambungan. Perlindungan konsumen yang di lakukan BPOM hanya berdasarkan peringatan-peringatan atau sanksi administratif kepada pelaku usaha. BPOM melindungi konsumen dengan cara semua produsen obat harus membuat label informasi yang disebut penandaan harus selengkap mungkin, jelas dan tidak menyesatkan.

Akibat bagi produk obat yang tidak memenuhi standar pelabelan adalah apabila ditemukan obat yang tidak memenuhi standar pelabelan yang sudah disyaratkan, maka BPOM pusat akan memberikan sanksi administratif berupa peringatan, dan pemberentian kegiatan. Untuk menghindari kemungkinan-kemungkinan adanya produk yang tidak sesuai dengan label yang beredar, maka perlu ditetapkan standart minimal yang harus dipedomani dalam memproduksi suatu produk yang layak dan aman untuk dipakai/dikonsumsi.

\section{Saran}

Sebaiknya konsumen harus lebih teliti untuk membeli obat yang sudah beredar, karena pada kenyataannya minimnya pengetahuan konsumen akan perlindungan konsumen menjadikan konsumen sebagai pihak yang dirugikan dalam segala aspek. Sebaiknya pengawasan yang di lakukan BBPOM terhadap peredaran obat di kota medan perlu di tingkatkan tidak hanya menunggu dari keluhan konsumen, tetapi harus berperan aktif dalam mengawasi segala bentuk penjualan atau peredaran obat. 
Jurnal Ilmu Hukum

FAKULTAS HUKUM UMSU
Perlindungan Hukum Terhadap...(Muhammad Ferdian) Volume 3 Nomor 2, Juli-Desember 2018, 166-184 DOI: https://doi.org/10.30596/dll.v3i2.3158

\section{DAFTAR PUSTAKA}

Barkatullah, Halim Abdul. (2010). Hak-Hak Konsumen. Bandung: Nusa Media.

Harianto, Dedi. (2010). Perlindungan Hukum Bagi Konsumen Terhadap Iklan yang Menyesatkan. Bogor: Ghalia Indonesia.

Kitab Undang-undang Hukum Perdata (KUHPerdata).

Kristiyanti, Tri., \& Calina, Siwi. 2008. Hukum Perlindungan Konsumen. Jakarta: Sinar Grafika.

Marzuki, Peter Mahmud. (2011). Penelitian Hukum. Jakarta: Kencana Prenada Media Group.

Muthiah, Aulia. (2018). Hukum Perlindungan Konsumen. Yogyakarta: Paper Plane.

Nasution, Az. (2011). Hukum Perlindungan Konsumen Suatu Pengantar. Yogyakarta: Diadit Media.

Peraturan Badan Pengawas Obat dan Makanan Nomor 12 Tahun 2018 Tentang Organisasi dan Tata Kerja Unit Pelaksana Teknisi Lingkungan Badan pengawas Obat dan Makanan.

Peraturan Pemerintah Nomor 51 Tahun 2009 Tentang Pekerjaan Kefarmasian.

Rahmawati, Nur Intan, dkk. (2014). Win-Win Solution Sengketa Konsumen. Jakarta:Pustaka Yustisia.

Seokanto, Sorejono., \& Muji, Sri. (1996). Pengantar Penelitian Hukum. Jakarta: UI Press.

Seokanto, Sorejono., \& Muji, Sri. (2003). Penelitian Hukum Normatif Suatu Tinjauan Singkat, Jakarta: Rajawali Pers.

Sidabalok, Janus. (2014). Hukum Perlindungan Konsumen di Indonesia. Bandung: Citra Aditiya Bakti.

Sutedi, Adrian. (2008). Tanggung Jawab Produk Dalam Hukum Perlindungan Konsumen. Jakarta: Ghalia Indonesia.

Undang-Undang Dasar 1945 (UUD 1945).

Undang-Undang Nomor 36 Tahun 2009 Tentang Kesehatan.

Undang-Undang Nomor 8 tahun 1999 tentang Perlindungan Konsumen. 